\section{Darwin on Dust at Sea}

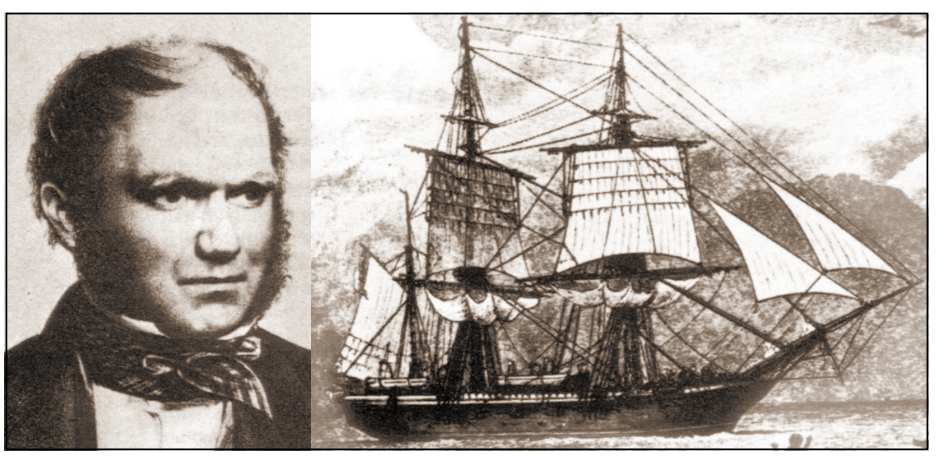

In their interesting contribution "The Chinese loess plateau - far and wide" (PAGES Newsletter 98-1) Biscaye and Grousset state that the record of modern eolian dust transport beyond the borders of continental deserts has been known for decades, at least since Radczewski 1939. They could have cited also Darwin who in 1833, a hundred years before Radczewski's report, mentioned "atmospheric dust" off the Cape Verde Islands on board of the HMS Beagle "dirtying everything on board and even hurting people's eyes" (see his Journal of Researches, 1845, chapter 1).

Darwin was well aware that this dust originated from Africa. However, Ehrenberg (1844, 1845 Monatsber. Berlin Ak. Wiss.), studying Darwin's and other dust samples collected at sea, found remains of siliceous skeletons of diatoms and phytoliths of plants, some of which he knew only from S. America. Darwin in his later "account of the fine dust which often falls on vessels in the Atlantic Ocean" (Quart. J. Geol. Soc. London, 1846) refers again to his observation on the Beagle as well as to many scattered accounts concerning dust which had fallen on ships on the African side of the Atlantic Ocean. Darwin concludes an African origin, because of the increase of dust towards the African coast and the wind direction, dismissing Ehrenberg's finding of some S. American diatoms. Maury (1855) in his well known "Physical Geography of the Sea" devotes part of his chapter 4 (6 in later editions) to dust at sea, the so called "red fogs" probably well known to sailors even long before Darwin. He tries to explain the presence of S. American diatoms in the dust observed by Ehrenberg as due to a transport from the Amazon and Orinoco basins in higher layers of the atmosphere. Maury also refers to a description of a wind-spout in the dry season in Orinoco basin observed by Alexander von Humboldt and described in his "Ansichten der Natur" (1807) to explain how dust particles can be transferred to high in the atmosphere.

In 1849 Darwin again mentioned aerial dust in his contribution on Geology in Herschel's "Manual of scientific Enquiry". He urged travelers to collect the dust falling on ships in the middle of the Atlantic, and make notes on day and location, indicating also the direction and force of the wind on the day itself and the previous days. Darwin was very interested in the provenance of this dust, a topic which remains an active research topic in our times.

\section{Gerhard C. Cadée}

Netherlands Institute for Sea Research, Den Burg, Netherlands cadee@nioz.nl

\section{Picture CRedits}

Down House Archive (HMS Beagle), Drawing by T. Magire (Darwin)
(* indicates open meetings. All interested scientists are invited to attend)

January 26-28, 1999 "Marine Environment, the Past, Present and Future". Kaohsiung, Taiwan

Contact: Chen-Tung Arthur Chen, Institute of Marine Geology and Chemistry, National Sun Yat-Sen University, Kaohsiung, Taiwan. Tel: +886-7-525 5146, Fax: +886-7-525 5346 ctchen@cc.nsysu.edu.tw

*February 13-18, 1999 "Glacial-Interglacial Sealevel Changes in Four Dimensions: Quaternary Sealevel, Climate Change and Crustal Dynamics". Albufeira, Portugal

Contact: Dr. Josip Hendekovic, European Science Foundation, 1 quai Lezay-Marnésia, 67080 Strasbourg, France. Tel: +33 388767135 , Fax: +33 388366987 euresco@esf.org; http://www.esf.org/euresco/Lc99087a.htm

*March 15-19, 1999 "International workshop on sediment transport and storage in coastal sea-ocean system". Tsukuba, Japan

Contact: Yoshiki Saito, Marine Geology Department, Geological Survey of Japan, Higashi 1-1-3, Tsukuba, Ibaraki 305-8567, Japan. Fax. +81-298-54-3533, Phone +81-298-54-3772 yoshi@gsj.go.jp

*March 26-April 1, 1999 "Loessfest 99 - Loess: Characterization, Stratigraphy, Climate and Societal Significance". Bonn and Heidelberg, Germany Contact: Ludwig Zoeller, Geogr. Inst., University of Bonn, Meckenheimer Allee 166, D-53115 Bonn, Germany. Phone: +49-228-735398 zoeller@slide.giub.uni-bonn.de; http://www.gg.rhbnc.ac.uk/loessfest

\section{*March 28-April 1, 1999 "European Union of} Geosiences meeting (EUG 10)". Strasbourg, France Contact: By indvidual symposia, see website below http://eost.u-strasbg.fr/EUG/symposia.html

May 6-14, 1999 "IGBP Congress (with PAGES Scientific Steering Committee Meeting)". Yokahama, Japan IGBP Contact: IGBP Secretariat, Royal Swedish Academy of Sciences, Lilla Frescativägen 4, Box 50005, S-104 05 Stockholm, Sweden Tel: +46816 64 48, Fax: +4681664 05; sec@igbp.kva.se PAGES Contact: Frank Oldfield, PAGES IPO, Bärenplatz 2,3011 Bern, Switzerland. Tel: +41313123133, Fax: +41313123168 oldfield@pages.unibe.ch; http://www.pages.unibe.ch

May 21-27, 1999 "Palaeoclimate Modelling and Analysis: Quaternary Earth System Interactions and Modelling". Albufeira, Portugal

Contact: Dr. Josip Hendekovic, European Science Foundation coordinates see above (February)

*August 3-11, 1999, "The Environmental Background to Hominid Evolution in Africa - INQUA XV International Congress". Durban, South Africa Contact: Dr D.M. Avery - Secretary General, South African Museum, P.O. Box 61, Cape Town 8000, South Africa.

Tel: +27-21-243330, Fax: +27-21-2467

mavery@samuseum.ac.za; http://INQUA.geoscience.org.za

September 17-22, 1999, "Polar Regions and Quaternary Climate: Towards High-Resolution Records of the Last Glacial Period in Antarctica". Giens, France Contact: Dr. Josip Hendekovic, European Science Foundation coordinates see above (February) 